\title{
The Effectiveness of Mathematics in Context Learning Model with Open Ended Approach to Mathematical Creative Thinking Ability
}

\author{
Nurkaromah Dwidayati ${ }^{1}$, Siti Aminah ${ }^{2}$, and Mulyono ${ }^{3}$ \\ \{noengkd_unnes@yahoo.co.id ${ }^{1}$, cety9947@gmail.com²,mulyono.mat@mail.unnes.ac.id ${ }^{3}$, \} \\ FMIPA Universitas Negeri Semarang ${ }^{1,3}$, \\ Postgraduate of Universitas Negeri Semarang, Semarang ${ }^{2}$
}

\begin{abstract}
The study was motivated by low mathematical creative thinking ability and preparation for the XXI century 4.0 disruption era. Mathematics in Context (MiC) is a learning model that links learning content with the real world and open ended questions to train students' creative thinking ability. The aim of this study was to know the effectiveness of the MiC learning model with open ended approach to mathematical creative thinking ability. Data analysis used a proportion of one party test, one party average test, two proportion difference test, and two average difference test. The result showed that the students who used MiC learning with an open-ended approach were effective on mathematical creative thinking ability. Based on the result, the MiC model with an open-ended approach needs to be a consideration for teachers to carry out in learning.
\end{abstract}

Keywords: Mathematics in Context, Open Ended Approach, Creative Thinking Ability.

\section{Introduction}

Industrial Revolution 4.0, Indonesia is on the verge of problems in managing human resources [1]. To compete in disruption era, creative thinking is needed [2]. Based on the results of the Trend International Mathematics and Science Study (TIMMS), the ability to think creatively in Indonesia is only $2 \%$ [3].

creative thinking is an extraordinary and unusual activity by combining seemingly unrelated information and triggering new solutions or ideas that show fluency, flexibility, originality in thinking and elaboration [4]. Open ended questions presented have more than one correct answer so that diverse answers give students the opportunity to find something new, try to find other alternatives, and connect between problems. [5].

One of materials that requires mathematical creative thinking is social arithmetic. The percentage of students' completeness who answered correctly on material related to social arithmetic in Balangan Regency based on 2018 UN results was 27.51 [6]. The result of the preliminary study at MTsN 1 Balangan, South Kalimantan Province showed that the students' average of mathematical creative thinking ability was 38.32. The result of the observation showed that the study in the classroom rarely gave real-world-related questions and it was still teacher-centered. Whereas, the 2013 curriculum learning model that was applied at MTsN 1 Balangan was Problems Based Learning. 
The Mathematics in Context (MiC) learning model can be a solution to the problem. Mathematics in Context is learning mathematics related to daily life where this learning model helps the teachers and the students link the content by connecting mathematics with problems in the real world so that the learning becomes meaningful [7]. Those are the learning steps of Mathematics in Context (1) Analyzing textbooks from other subjects that related to mathematics learning material will be taught, (2) Communicating learning objectives, (3) Resolving contextual problems (4) Developing mathematical topics and concepts that are needed for mathematical models and solutions, (5) Determining models, (6) Formulating solutions of problems, (7) Determining appropriate solutions, (8) Interpreting solutions in terms of situational contexts, and (9) Drawing conclusions and demonstrating [8].

Problem Based Learning is learning that is designed by giving a problem to the students but the teacher conveys some information or material so the students learn to build their concepts independently through the problem [9] Langkah-langkah pembelajaran PBL yaitu (1) orienting problems to the students; (2) organizing the students to conduct the research; (3) assisting independent and group investigations; (4) developing and presenting works; (5) analyzing and evaluating the problem solving process. The effectiveness of learning is measured by the students' achievement of learning objectives [11]. Learning effectiveness criteria are (1) knowing the proportion of students' creative thinking ability in the MiC learning model with open ended approach to achieve completeness more than $75 \%$, (2) knowing the average mathematical creative thinking ability of the students in the $\mathrm{MiC}$ learning model with an open ended approach beyond actual completion limit, (3) knowing the proportion of mathematical creative thinking ability in the MiC learning model with open ended approach to be more than proportion in the PBL learning model, (4) knowing the students' average ability to think creatively in the MiC learning model with an open ended approach to be more than the students' average in the PBL learning model [12].

\section{Methods}

This study was a quasi-experimental study. Data collection methods used in the study were observation, tests, documentation, and literature reviews. Classes were chosen randomly with the provisions of a normal distribution, homogeneous classes, and the averages of both classes of each gender having a statistical similarity before being given treatment. The population in this study was VII grade students in the even semester MTsN 1 Balangan academic year 2018/2019. The sample was chosen by cluster random sampling technique.

The preliminary test was given to find out the actual completion limits and chose the class to be used as an experimental class based on gender that used MiC learning, while the control class was based on gender that used the PBL model. Class VII 1 and VII 4 were chosen as the experimental classes of male and female, while classes VII 3 and VII 6 respectively were chosen as control classes of male and female, and class VII 5 was chosen as a trial class. The limit of an actual completion was based on the average score which was reached by the student groups [13]. To determine the limit of the actual completion would be obtained with the formula (1):

$$
\bar{x}+0,25 \mathrm{SD}
$$

Based on the formula (1), it was obtained that the limit of the actual completion was 42 . Then, it was continued by testing the homogeneity and normality of the final data. The 
normality test was carried out by the Kolgorov-Smirnov test and homogeneity test was carried out by the Levene test [14]. Classical completeness test used proportion test [15]. The average completeness test used one sample $t$ test, the average difference test used the independent $t$ test [14]. The MiC questions with the open ended approach were collected through survey and interview in December 2018. The study was conducted in April-May 2019.

\section{Result and Discussion}

Mathematics learning model in context model with open ended approach was held four meetings. The implementation was carried out outside the classroom at two meetings, namely the first meeting and the forth meeting while the second and the third meetings were given real problems around the students.

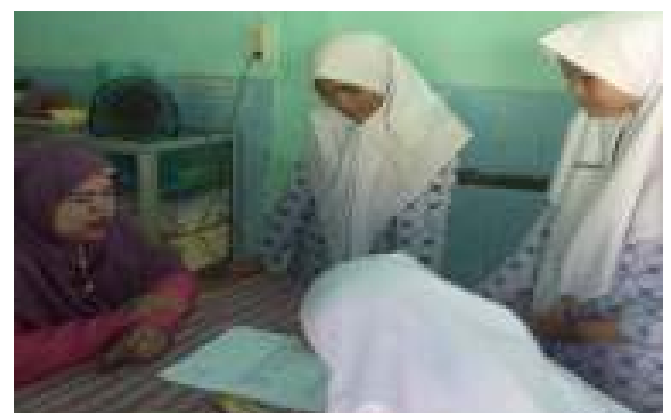

Fig. 1. the female experimental class recorded information provided by cooperative officers.

Figure 1 showed the first meeting of MIC learning which was done in school cooperative where the students were searching information to the officers of school cooperative to get the data of buying and selling price.

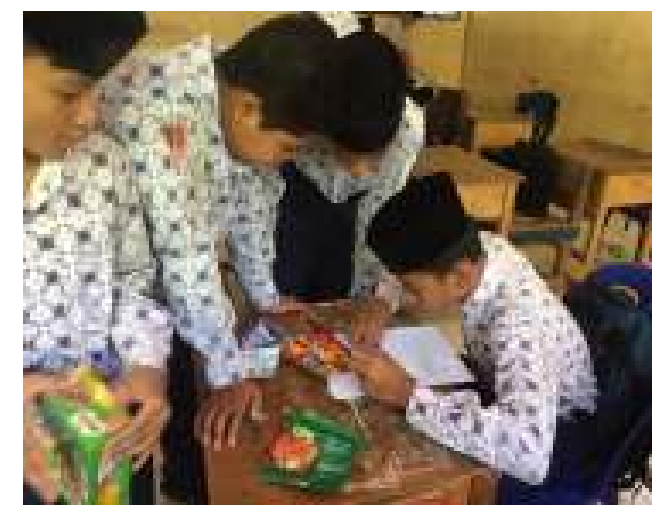

Fig. 2. The male experimental class analyzed snacks they had bought. 
Figure 2 showed the fourth meeting of MIC learning where the students bought a snack showing net in its pack to be analyzed then it was discussed by groups related to the gross, tare and net material.

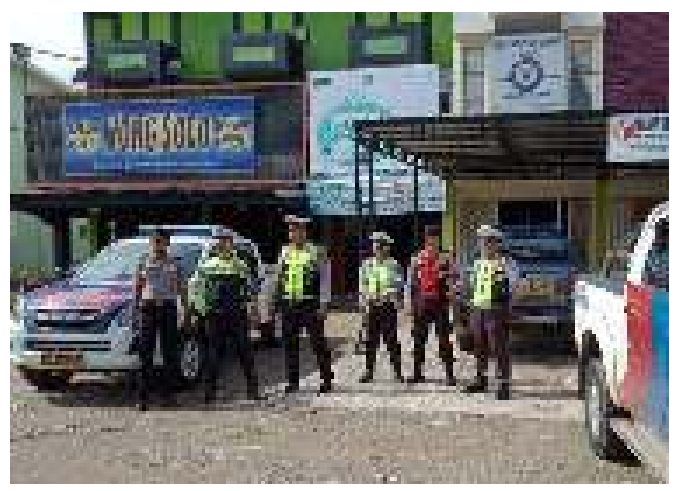

Fig. 3. Wong Solo Restaurant, Paringin, South Kalimantan.

In Figure 3, the students were given problems related to tax and discount where it was done in the restaurant located near the school in the second meeting.

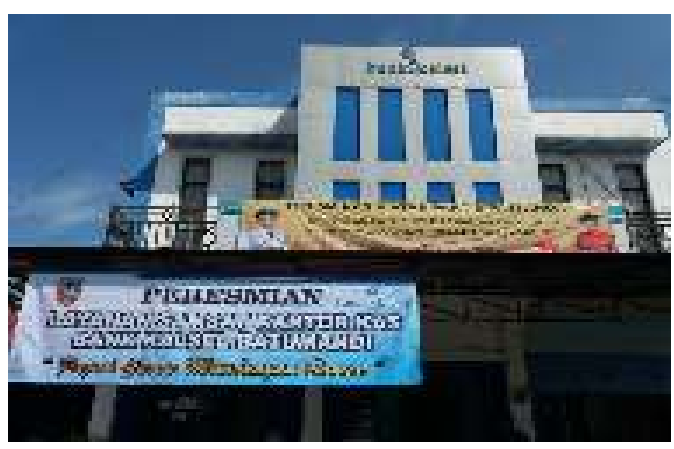

Fig. 4. Bank Kalsel in Batumandi, South Kalimantan.

Figure 4 showed that the students were given problems related to interest in a Bank which was located near the school but they had never visited it. Based on the initial data analysis, the result showed that the samples taken from the population which had normal distribution had homogenous variance. Moreover, the initial average score of the experimental class students was the same as the control class students. It showed that the samples of this study had the same initial condition. Table 1 showed the final result of creative thinking ability tests. 
Tabel 1. Final Results of Creative Thinking Ability Tests

\begin{tabular}{cccccc}
\hline Class & $\mathrm{N}$ & Average & $\begin{array}{l}\text { Standar } \\
\text { Deviation }\end{array}$ & $\begin{array}{c}\text { Highest } \\
\text { Score }\end{array}$ & $\begin{array}{c}\text { Lowest } \\
\text { Score }\end{array}$ \\
\hline VII 1 & 34 & 58.52 & 17.71 & 90 & 10 \\
VII 3 & 34 & 50.10 & 19,98 & 83 & 10 \\
VII 4 & 28 & 56.25 & 18.59 & 88 & 21 \\
VII 6 & 29 & 47.41 & 16,21 & 83 & 10 \\
\hline
\end{tabular}

Based on the result of analyzing the final test of mathematical creative thinking ability in Table 1, it was obtained that the students who used MIC learning model with open ended approach reached the completion. Descriptively, class VII 1 from 34 students, 30 of them got scores above actual completion limit. It means the percentage of students' creative thinking abilities in a descriptive manner was $88.23 \%$. Statistically, the result of class VII 1 from the proportion of one party test got score of $z_{\text {count }} 1.78$ and $z_{\text {tabel }} 1.64$ because $z_{\text {count }}>$ $z_{\text {tabel }}$ then $\mathrm{H}_{0}$ is rejected. While descriptively, class VII 4 from 28 students, 25 of them got scores above actual completion limit. It indicates that the percentage of students' creative thinking ability in a descriptive manner was $89.29 \%$. Statistically, the results of the proportions of one party test class VII 4 got the score of $z_{\text {coum }} 1.74$ and $z_{\text {tabel }} 1.64$ because $z_{\text {count }}>z_{\text {ta }} \overline{e l}$ then $H_{0}$ was rejected so it could be concluded that the proportion of students in the class taught by MiC learning model that scores mathematical creative thinking abilities reached the limit actual completion exceeded $75 \%$.

Descriptively, the students in class VII 1 got an average mathematical creative thinking ability 58.52. Statistically, the average test results of class VII 1 got score of $t_{\text {coun }} 5,43$ while a significance level of $5 \%$ was obtained $t_{\text {tabis }}=1.69$ because $t_{\text {woun }}>t_{\text {tahls }}$ then $H_{0}$ was rejected and it was concluded that the average mathematical creative thinking ability of students who used the MiC learning model reached an actual completion limit. Descriptively, class VII 4 as the experimental class got an average mathematical creative thinking ability 50.10. Statistically, the average completeness test results of class VII 4 got score of $t_{\text {cownat }}=$ 4.04 while the $5 \%$ significance level was obtained $t_{\text {table }}=1.70$ because $t_{\text {coune }}>t_{\text {abale }}$ then $\mathrm{H}_{0}$ was rejected and it could be concluded that the students' average mathematical creative thinking ability using the MiC learning model was more than 42 .

Descriptively, the proportion of completeness in class VII 1 using the MiC learning model with open ended approach was $88.23 \%$ while the completeness proportion of class VII 3 using PBL learning was $70,58 \%$. Statistically, the comparison of the completeness proportions of the two classes between the female experimental class and female control class were seen from the comparison of the $\mathrm{z}$ test. From the calculation, it was obtained $z_{\text {rount }}=2.003$ while the significance level of $5 \%$ was obtained $z_{\text {tadel }}=1.64$. It appears that $z_{\text {count }}>z_{\text {tabel }}$. Thus it was concluded that the proportion of completeness of the female class using the MiC learning model with open ended approach was more than the female class using the PBL learning 
model. Whereas the completeness proportion of class VII 4 using the MiC learning model with open ended approach was $89.29 \%$ while the completeness proportion of class VII 6 using PBL learning was $68.96 \%$. Statistically, the comparison of the completeness proportions of the two classes between the male experimental class and the female experimental class could be seen from the comparison of the $\mathrm{z}$ test. From the calculation obtained $z_{\text {ewn }}=1.88$ while the

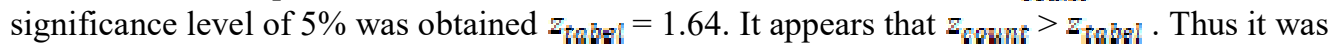
concluded that the proportion of completeness of the male class using the MiC learning model with open ended approach was more than the male class using the PBL learning model.

Descriptively, the average score of the final test of mathematical creative thinking ability of class VII 1 was 58.52 while the average score of the final test of mathematical creative thinking ability of class VII 4 was 50.10. Statistically, the comparison of the average score of the creative thinking ability test in the female class could be seen from the results of the $t$ test. From the calculation, it was obtained $t_{\text {cownt }}=1.76$ while the significance level of $5 \%$ was obtained $t_{\mathrm{w} w \mathrm{l}}=1.67$. Descriptively, the average score of the final test of mathematical creative thinking ability of class VII 4 was 56.25 while the average score of the final test of mathematical creative thinking ability of class VII 6 was 47.41. Statistically, the comparison of the average score of the creative thinking ability test in the female class could be seen from the results of the $\mathrm{t}$ test. From the calculation, it was obtained $\mathbf{t}_{\text {eoum }}=1.98$ while the significance level of $5 \%$ was obtained $t_{\text {ta bel }}=1.67$. It could be seen that $t_{\text {count }}>t_{\text {tabel }}$, it could be concluded that the average mathematical creative thinking ability using MiC learning with open ended approach was more than the average mathematical creative thinking ability using PBL learning.

The results of this study supported that the application of Mathematics in Context (MiC) was effective in classroom learning [16] [17] [18] [19] and open ended approach was effective to creative thinking ability [20] [21].

\section{Conclusion}

Mathematics in Context learning with open-ended approach is effective on the ability to think creatively. It can be seen from the indicators: the ability to think creatively in the class that used MiC learning with open ended approach reached completion, that was, at least $75 \%$ of all participants in the class, both male and female achieve minimal creative thinking ability test scores 42 , the average scores of the final test of creative thinking ability in the class that used MiC learning with open ended approach exceeded the actual completion limit score of 42 both female and male classes, the proportion of class completion that used MiC learning with open ended approach was more than the proportion of class completion that used PBL learning in both female and male classes, the average scores of the final test of the creative thinking ability of the class that obtained MiC learning with open ended approach was more than the students' average that used PBL learning of both female and male classes. To sum up, the teacher can associate the content of learning with the real world to make it easier for the students to understand the subject matter and face problems in the real world. 


\section{References}

[1]Yohanes, E.H. Tiga Soal Utama Pemberdayaan Pendidikan di Indonesia. Kompas.com. (2019).

[2] Peter, E. E. Critical Thinking: Essence for Teaching Mathematics and Mathematics Problem Solving Skills. African Journal of Mathematics and Computer Science Research, Vol. 5(3), pp. 39-43. (2012).

[3] Mullis, I. V. S., et al. TIMSS 2011 International Results in Mathematics. Amsterdam: International Association for Evaluation of Educational Achievement. (2012).

[4] Munandar. Pengembangan Kreatifitas Anak Berbakat. Jakarta: Rineka Cipta. (2009).

[5] Foong, P. Y. Open Ended Problems for Higher Order Thinking in Mathematics. Singapore. Institute of Education Singapore. (2000).

[6]Kemendikbud. Hasil Ujian Nasional 2018. Available: https://puspendik.kemdikbud.go.id/hasilun/.(2018).

[7]Titikusumawati. Penerapan MiC Melalui Cycle Learning untuk Meningkatkan Pemahaman dan Aplikasi Konsep Matematika Siswa MA NW Pancor Lombok Timur NTB. (2009).

[8] Camarena, G. P. Mathematical Modeling and Knowledge. Journal of Mathematical Modelling and Application. Vol. 1(1), 18-36. (2009).

[9] Arends, Richard. Belajar untuk Mengajar. Yogyakarta: Pustaka Pelajar. (2008).

[10]Nafiah, Y.N. \& Suyanto, W. Penerapan Model Problem Based Learning untuk Meningkatkan Keterampilan.(2014).

[11]Setyosari, P. Menciptakan Pembelajaran yang Efektif dan Berkualitas. Jurnal Inovasi dan Teknologi Pembelajaran, Vol. 1(1), pp. 20-30. (2014).

[12]. E. Pujianto a Masrukan, "Analisis Kemampuan Komunikasi Matematis Model Round Club dengan Self Assesment Bernuansa Etnomatematika Berdasarkan Gaya Kognitif”, Unnes Journal of Mathematics Education Research, zv. 5, \%1. vyd.1, pp. 81-89, (2017).

[13]Sudjana, N. Penilaian Hasil Proses Belajar Mengajar. Bandung: Remaja Rosdakarya. (2009).

[14]Riadi, E. Statistika Penelitian (Analisis Manual dan IBM SPSS). Yogyakarta: Penerbit Andi. (2016).

[15]Sudjana. Metoda Statistika. Bandung: Tarsito. (2005).

[16]Saputra, Apis, dan Fachruddin, M., dan Zamzaili. Penerapan Pembelajaran Mathematics in Context (MiC) untuk Meningkatkan Hasil Belajar Matematika Siswa SMP Negeri 21 Kota Bengkulu. UNIB Scholar Repository: Fakultas Keguruan dan Ilmu Pendidikan UNIB. (2009).

[17]Endramawati, T., Mastur, Z. and Mariani, S."Mathematical Literacy Based On Entrepreneurial Character Students on Problem Based Learning Nuance of Mathematics In Context". Unnes Journal of Mathematics Education Research. (2019).

[18]Millaty, V., Kartono, K., \& Karomah Dwidayati, N. (2019). "Students' Mathematical Connection Ability and Self Regulated Learning on MiC Learning with Recitation and Peer Assessment Based on Semarang Culture". Unnes Journal of Mathematics Education Research

[19]Eka, F,F. Pembelajaran Matematika dengan Pendekatan Mathematics In Context Pada Kemampuan dan Keterampilan Berpikir Kreatif . JES-MAT. ISSN: 2460-8904. Vol.3. No.1. (2017).

[20]Karina, P, Sugiarto, Emi. P. Keefektifan Pendekatan Open-Ended dengan Pembelajaran Kontekstual terhadap Kemampuan Berpikir Kreatif. UJME(1). ISSN 2252-6927. (2013).

[21]Dori,L.H, Nani, D. Efektivitas Pendekatan Open-Ended Terhadap Kemampuan Berpikir Kreatif Matematika Siswa SMP. Seminar Nasional Riset Inovatif II. ISSN: 2339-1553. (2014). 